Violeta Sima ${ }^{1}$

Ileana Georgiana Gheorghe ${ }^{2}$
JEL: 011, 052, Q56

DOI: 10.5937/industrija45-14121

UDC: 338.242.2(498)"2008/2014"

330.45:519.816

Original Scientific Paper

\title{
A multicriterial Analysis of National Competitiveness: Evidences for a Resilient Economy
}

\author{
Article history: \\ Received: 24 April 2017 \\ Sent for revision: 6 May 2017 \\ Received in revised form: 26 May 2017 \\ Accepted: 28 May 2017 \\ Available online: 1 July 2017
}

\begin{abstract}
This article is structured in three parts, as follows: In the first part, we summarized the different approaches of national competitiveness in the literature on the economic performance assessment, using specific indexes: Global Competitiveness Index (GCl), Ecological Performance Index (EPI), and Human Development Index (HDI), highlighting their advantages and limitations. These variables were analyzed ante-crisis and ex-crisis, assuming that the economic recession could generate some effects. Data sources are presented at the beginning of the 'Results and discussion' paragraph. Considering the diversity of the issues and the inhomogeneity of data describing those issues, GDP was used along with the four composite indicators: $\mathrm{GCl}, \mathrm{EPI}, \mathrm{HDI}$, and Economic Resilience Index (ERI). The third part presents the main findings and their implications. Thus, a downward trend of the evolution of Romania's economic resilience index during 20082014 was observed. This decline appears to be due largely to the decrease in Social development sub-index and in Governance sub-index. The low level of the Romanian economy resilience is mainly explained by the low level of competitiveness and productivity of production factors. The obtained outcomes suggest that in addition to national competitiveness assessing, ERI evaluation is important because it can reveal the hidden sources of vulnerability of the economy to external shocks.
\end{abstract}

\footnotetext{
${ }^{1}$ Petroleum-Gas University of Ploiesti, Romania, Faculty of Economic Science, vsima@upg-ploiesti.ro

2 Petroleum-Gas University of Ploiesti, Romania, Faculty of Economic Science 
Sima V., Gheorghe I.G.: A multicriterial Analysis of National Competitiveness...

Keywords: Indexation, Competition, Competitiveness; Global Competitiveness Index; Ecological Performance Index; Human Development Index; Economic Resilience Index.

\section{Multikriterijumska analiza nacionalne konkurentnosti: Dokazi otpornosti ekonomije}

Apstrakt: Rad je strukturiran u tri celine: $U$ prvoj celini, sumarizovani su, u dostupnoj literature, različiti pristupi nacionalnoj konkurentnosti, odnosno procena ekonomskih performansi uz pomoć specifičnih indeksa: Indeksa globalne konkurentnosti (GCl), Indeksa ekoloških performansi (EPI) i Indeksa ljudskog razvoja (HDI), pri čemu je ukazano na njihove osnovne prednosti i ograničenja. Varijable su analizirane kao predkrizne i postkrizne, pod pretpostavkom da bi ekonomska recesija mogla proizvesti određene efekte. Izvori podataka su predstavljeni u odeljku Rezultati rada sa diskusijom. S obzirom na veliku raznolikost pitanja i nehomogenost podataka koji opisuju pomenuta pitanja, istraživanja su podrazumevala korišćenje BDP zajedno sa sledećim kompozitnim indikatorima: GCl, EPI, HDI i Indeksom ekonomske otpornosti (ERI). U trećem delu prikazani su osnovni rezultati rada $i$ njihove potencijalne implikacije. Primećen je negativan trend razvoja Indeksa ekonomske otpornosti za Rumuniju, tokom perioda 2008-2014. godina. Pretpostavlja se da je uočeni pad u velikoj meri posledica pada vrednosti pod-indeksa socijalnog razvoja $i$ pod-indeksa vladavine prava (korupcije). Nizak nivo otpornosti rumunske ekonomije se prevashodno objašnjava niskim nivoom konkurentnosti $i$ produktivnosti proizvodnih faktora. Dobijeni rezultati sugerišu da je pored evaluacije nacionalne konkurentnosti, neophodna i procena ERI indeksa, s obzirom da ona može otkriti skrivene izvore ranjivosti nacionalne ekonomije na eksterne šokove.

Ključne reči: Indeksiranje; Konkurencija; Konkurentnost; Indeks globalne konkurentnosti; Indeks ekoloških performansi; Indeks ljudskog razvoja; Indeks ekonomske otpornosti.

\section{Introduction}

'The sustainability revolution' is considered by some authors (Edwards, 2005) as being the movement that generated the most powerful cultural transformation since industrial and agricultural revolutions. The essence of this movement consists in that it assumes that human society in all its forms depends on both the socio-economic factors, but also the environmental ones. Worldwide, a real result is easy to notice. The interest and involvement to achieve a more sustainable world are becoming stronger (Esty \& Winston, 2006; Hawken, 2008; Hawken, 2008; Jacobson \& Delucchi, 2009; Marcus, 
Sima V., Gheorghe I.G.: A multicriterial Analysis of National Competitiveness...

Geffem, \& Sexton, 2002; Orr, 1994; Russo, 2008; Starik \& Heuer, 2002). To do this, education is very important. Thus, increasingly more people are interested to know environmental issues and manage initiatives in this respect. There is a vast variety of actions, from the personal concerns saving water, energy, waste recycling - to initiatives at the community level (Danaher, 2007).

Despite the growing importance of sustainability in management literature, the theoretical development in the field of sustainability has not yet permitted to obtain a model that fully recognized the elements involved. Most of the researchers agree that the constantly changing organizational and environmental issues and their long-term implications represent a key element. Also, the interdependence and integration of human relationships, organizations and society and the paradoxical requirements inherent in a dynamic society are named, too (Dobre, Stanila, \& Brad, 2015; Burns, 2012).

In the literature, several indexes are used to evaluate the three areas of the sustainable development strategy, economic, social and environmental. The most used indexes are: Global Competitiveness Index (GCl), Human Development Index (HDI), Environmental Sustainability Index (ESI), Environmental Performance Index (EPI).

The European Union aims to replace the linear growth model with a circular one. The basic idea of the circular economy is reuse, repair, and recycling of materials and products, unlike the linear model, which assumes that resources are sufficient, available and inexpensive removed. The main idea of the circular model is the maintaining of the products in use for longer and generating minimal amounts of waste while reducing pressure on natural resources and on the environment. It could represent a way toward a more competitive and resilient economy.

In fact, the major challenge of the 21st century is an economy based on low energy consumption and low raw materials consumption. In this system, the waste should have precise destinations since the design stage. Thus, it can be stated that the waste converted into resources is a key element of the circular economy. In this system, the processes of production and consumption are based on reuse, repair, and recycling, generating multiple benefits. The main benefits generated by the circular economy are the creation of new jobs in all phases of production and consumption, a global economic competitiveness, an intelligent use of resources, an extent of the products life (modular design), and limiting waste.

The shift to the circular economy is on the EU agenda since 2014. A communicate is to be mentioned: 'Towards a circular economy: A zero waste programme for Europe' (Commission to the European Parliament, the Council, the European Economic and Social Committee and the Committee of 
Sima V., Gheorghe I.G.: A multicriterial Analysis of National Competitiveness...

the Regions, 2014). In 2015, the European Commission adopted an ambitious Circular Economy Package, including revised legislative proposals on waste. They aim to encourage businesses and consumers to switch to the circular model (Ellen MacArthur Foundation, 2013).

Nowadays worldwide, there is a shift of the changing factors toward building an efficient, resilient, solidarity economy. In this context, a question arises: 'What makes one economy more resilient than another?' A work stream on economic resilience has become a hot topic especially since 2009. It aims at early identification of vulnerabilities. Thus, governments can develop effective policies, reducing risks economic costs.

To help governments to detect vulnerabilities early, Röhn, O. et al. (2015) proposed a set of vulnerability indicators grouped into six areas: financial sector, non-financial sector, asset market, public sector, external sector, and international spillovers, contagion and global risks.

The purpose of this paper is to analyze the economic competitiveness of Romania, but, also, to assess to what extent it will continue to be strong, it will strengthen even further, or it will begin to weaken. Economic growth depends on the level of investments, technical progress and a better allocation of resources. In this regard, a new growth pattern is required. It should also focus on internal resources; new competitive advantages; education. The flexibility of a national economy is also important because it enables to come back after it has been affected by an external shock. Thus, the capacity for adaptation, self-organization, and learning of a socio-economic system will allow it to be resistant to shocks. This was called resilience.

\section{Premises}

\subsection{Literature review}

This paper assumes that while the economic growth generates the welfare, the well-being could be increased through development. In this respect, the authors considered a multidimensional approach, much larger than the only economic dimension. Average GDP per capita is accepted as a good measure for standard of living of a country, GDP measuring annual economic output. But GDP doesn't separate costs from benefits and, also, it doesn't say about how income and wealth are distributed among the people. In fact, even GDP's designer, Simon Kuznets (1955), observed this limit of GDP, stating that the welfare of a nation can scarcely be inferred from a measurement of national income. 
Sima V., Gheorghe I.G.: A multicriterial Analysis of National Competitiveness...

In the scientific literature, different authors have identified diverse types of relationships between different indicators (Radu, 2012; Kasimovskaya \& Didenko, 2013; Sima \& Gheorghe, 2014). Our analysis aims at evaluating the global competitiveness from the point of view of the sustainable development model. To assess the pillars of sustainable development five indexes were used. The total competitiveness of the national economy was assessed using Global Competitiveness Index (GCl). The pillar of economic performance was assessed using GDP per capita, and economic resilience index (ERI). The pillar of environmental performance was assessed using EPI. The pillar of social performance was assessed using HDI. HDI was considered in the analysis because it has more coverage than GDP per capita. HDI is constructed considering the social perspective - by the instrumentality of the health field and the education field - in addition to the economic perspective.

\subsection{Core concepts}

The idea to assess global competitiveness belongs to $M$. Porter of Harvard University (2000). A year later, at the World Economic Forum (WEF), Jeffrey Sachs and John McArthur introduced the Growth Competitiveness Index to evaluate the capacity of macroeconomic development (Schwab, Porter, \& Sachs, 2002, p. 19). At the microeconomic level, its assessment was proposed to be performed based on the Business Competitiveness Index. Later, at the World Economic Forum in 2005, Xavier Sala-i-Martin has proposed to replace it with the New Global Competitiveness Index (Sala-IMartin \& Artadi, 2005).

$\mathrm{GCl}$ measures the national competitiveness, requiring the annual gathering of data from many countries. It aims to evaluate national country's competitiveness to achieve sustained economic productivity, growth and prosperity (Sala-I-Martin X. G., 2012). This is built considering a set of three key factors for the level of productivity and efficiency of a country (Matei, Popescu, \& Radulescu, 2011). They are basic factors (public institutions, infrastructure, macroeconomic development, health \& primary education), efficiency factors (higher education and human resource training, market efficiency, responsiveness to modern technologies, labor market efficiency, financial market development), and innovation factors (market size, business sophistication, and innovation). The $\mathrm{GCl}$ can be distinguished by the inclusion of many indicators as determinant variables. They are pragmatically selected based on theoretical aspects explaining prosperity. The factors are grouped hierarchically into categories depending on how they affect competitiveness. Regarding the issues to be considered when selecting indicators two aspects are to be mentioned, namely, taxation policies and regulatory in the labor market because they have no simple linear relationship with prosperity. Thus, especially in developed countries, tax rates appear to be higher in countries 
Sima V., Gheorghe I.G.: A multicriterial Analysis of National Competitiveness...

with strong institutions and they invest more effective in social services. The case of the less developed countries is, however, to be mentioned, because these have also important level of taxation, but their spending in the public system is less efficient - unfortunately, this seems to be the situation in Romania. Thus, the econometric effect on competitiveness is harder to be pointed out. 'The New GCl aims to offer a framework to inform overall policy while establishing priorities at the specific policy level' (Schwab \& Porter, 2009). Thus, the $\mathrm{GCl}$ model aims to determine a general classification of countries according to competitiveness, to build an overall predictor of productivity.

Reports containing the EPI values began to be published since 2006 once every two years. EPI was developed from the Pilot Environmental Performance Index (first published in 2002 by Yale University's Yale Center for Environmental Law and Policy and Columbia's Center for International Earth Science Information Network in collaboration with the World Economic Forum and the Joint Research Centre (JRC) of the European Commission (Yale University). This index was designed to contribute to the achievement of the eight international development goals (Millennium Development Goals) stated at the Millennium Summit of the United Nations in 2000. The UNO has undertaken to achieve these goals until 2015. These objectives aim to the eradication of extreme poverty and hunger, achieving universal primary education level, promoting equality between men and women and empower women, reducing child mortality, improving maternal health, combat HIV / AIDS, malaria, and other diseases, ensuring environmental sustainability, and developing a global partnership for development. The EPI measures the environmental performance of a country's policies. It is defined using indicators that provide aggregate information expressed on a governmental scale of the way countries achieve their established environmental policy objectives.

The EPI is designed by computing and aggregation of 25 performance indicators grouped into two categories, namely Environmental Health including health impacts, air quality, water and sanitation, and Ecosystem Vitality, including agriculture, biodiversity and habitat, climate and energy, forests, fisheries, and water resources. This index was used since 2006. Before this, the Environmental Sustainability Index (ESI) was used. ESI is a composite index published during 1999-2005 built on 21 performance indicators that reflect national environmental data, grouped in five categories of policies aiming sustainability (Wackernagel, 2001): environmental system condition, reduction of environmental stress, reduction of human vulnerability, societal and institutional capacities to respond to environmental challenges, and global environmental responsibility (Haberland, 2008). The Environmental Performance Index was designed with the purpose of transnational use. It was found that EPI is a more complex quantitative indicator results-oriented 
Sima V., Gheorghe I.G.: A multicriterial Analysis of National Competitiveness...

and can be easily used by policy makers (Bhanu \& Raghbendra, 2003). That is why its use in formal reports Economic World was decided. In addition, the authors considered to draw attention to the fact that, at international level, there is a shortage of information on many substances and their effects on the environment and human health. It is emphasized the importance of uniformization of environmental data collection at international level. The environmental performance index should be considered as an indicator continuously developing (Haberland, 2008). By the other hand, the ecological performance is linked to the concept of sustainable performance.

The sustainable performance is assessed from three points of view, namely, economic, social and environmental. Economic performance is a function of the organization's economic interactions, measured by traditional financial indicators but not only (Caraiani, 2010). The environmental performance considers effects generated by the human activity over the natural systems. The social performance considers impacts of the organizations at local, national and global level. Social performance indexes can affect the organization's intangible assets such as human capital and reputation (Radu, 2012).

The Human Development Index (HDI) was proposed by Pakistani economist, Mahbub ul Haq, in the 'Human Development Report' published by the United Nations Development Program (UNDP) in 1999. This index was calculated based on four types indexes for the three fields (Haq, 1999). HDI assesses the extent to which a country manages to a successful development of its human capital. Having a broader coverage than GDP, HDI is measured considering other indexes, namely, GDP per capita for the economic field, average life expectancy for the health sector, and level of adult literacy and combined gross enrollment ratio for the field of education. The concept of human development highlights this indicator which reveals the structure and direction of progress (or regress) of human capital in the sustainable growth frame of an economy.

Addressing the issue of sustainability of the economy and the increasing complexity of society has imposed economic resilience consideration. It aims to identify critical issues to increase the capacity of an economy to avoid or recover the negative effects of shocks (Zaman \& Vasile, 2014). The economic resilience was defined as the capacity of an economy to resist a shock and to recover rapidly to the previous level of growth or better.

The economic resilience was defined as the capacity of an economy to resist to a shock and to recover rapidly to the previous level of growth or better. Briguglio et. al. has broadened the use of the concept of economic resilience, relating to the ability to: (i) recover quickly from a shock; and (ii) withstand the effect of a shock (Briguglio, Cordina, Farrugia, \& Vella, 2009). They performed a method to determine the index of the economic resilience (ERI) as an 
Sima V., Gheorghe I.G.: A multicriterial Analysis of National Competitiveness...

average of the following four indices: macroeconomic stability index; microeconomic market efficiency index; governance index and social development index. Three variables were considered in calculating the component of macroeconomic stability, namely (i) the fiscal deficit-to-GDP ratio; (ii) the sum of the unemployment and inflation rates; and (iii) the external debt-to-GDP ratio (Briguglio, 2003). The microeconomic market efficiency index assesses the extent to which (i) the banking industry is dominated by private firms; (ii) foreign banks are permitted to compete in the market; (iii) credit is supplied to the private sector; and (iv) controls on interest rates interfere with the credit market, referring to the degree of state involvement in the financial market. The authors argue that the flexibility of shock reaction of an economy is even higher with as the government's role is lower. The microeconomic efficiency index is a component of the Economic Freedom of the World Index (Gwartney, Lawson, \& Clark, 2002), namely 'regulation of credit, labour and business', covering five subcomponents, namely (i) judicial independence; (ii) impartiality of courts; (iii) the protection of intellectual property rights; (iv) military interference in the rule of law; and (v) political system and the integrity of the legal system. Social development index is calculated as the average of education and health indexes used to measure the human development index.

\section{Results and discussion}

The focus of our research is on the assessment of the competitiveness of a country. As we have shown above, a comprehensive indicator for assessing a country's competitiveness has not been constructed yet. This situation is explained by the diversity of the issues to be considered and the inhomogeneity of data describing those issues, GDP was used along with the four composite indicators, namely, GCI, EPI, HDI, and ERI.

Figure 1. (a) GDP evolution, 2006-2015; (b) GDP per capita evolution, 2006-2013

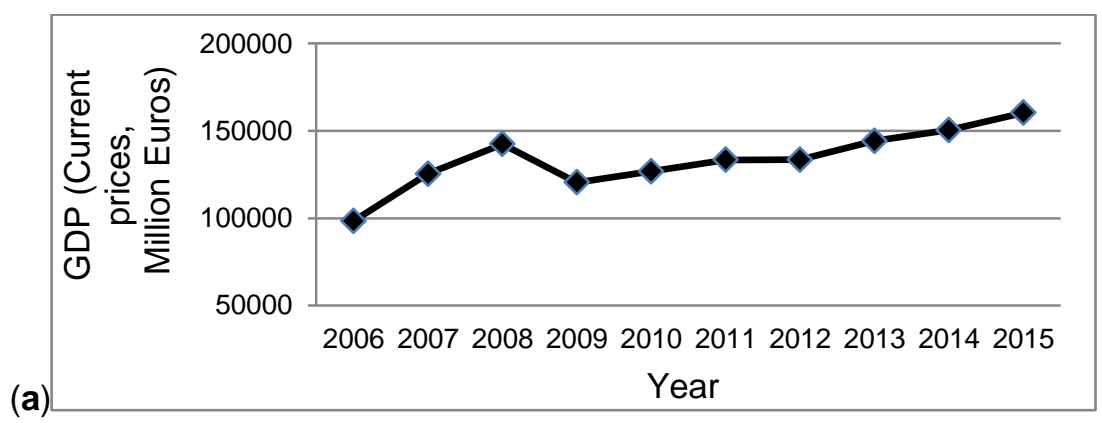


Sima V., Gheorghe I.G.: A multicriterial Analysis of National Competitiveness...

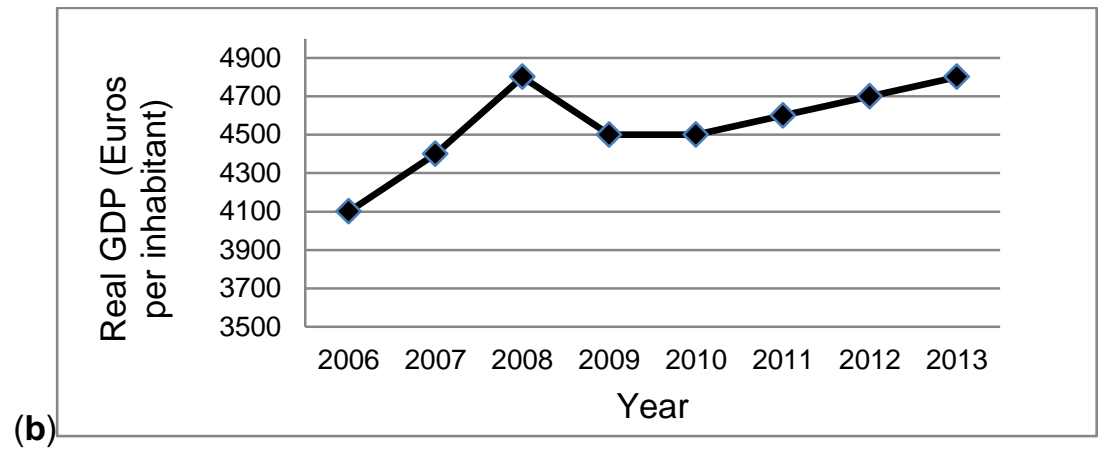

Source: Authors computations, based on Eurostat data, v3.1.18-20160921-5796PROD_EUROBASE, [nama_10_gdp]; [nama_aux_gph]

In Romania, during 2006-2015, GDP evolution showed a general upward trend. Before the crisis, in 2008, Romania was called the economic tiger of Europe, considering the continuous increasing of GDP during 2000-2008. During 2006-2008 annual growth rates of over 7\% have been recorded. In 2009 , there was a dramatic decrease by $7.1 \%$ compared to 2008 . During 2010-2015 the GDP's evolution is circumscribed to a process of recovery from recession (Figure 1.a). In 2011, the Romanian economic system recovery began, GDP recording an average real growth rate of 1.8\% during 2001-2015 (Programul de Convergenţă, 2016-2019, 2016). The evolution of GDP per capita was similar. (Figure 1.b).

In the period preceding the crisis, a rapid rate of growth was recorded in Romania, driven by domestic demand (consumption and investment). During 2001-2008, domestic demand was on average about 10.4\% per year in real terms, significantly above the growth rate of the real GDP $(6.3 \%)$. It shows that investment and consumption were covered largely by imports and not domestic production, generating the external imbalance (the current account deficit).

The rapid growth of consumption and investment was financed and supported by accumulating foreign debt in the private sector and by foreign direct investments. They are a more stable source of funding than the loans, stimulating the economic growth potential of the country. Public expenditure rose rapidly before 2008, fueling an overheating of the economy and leading to the deepening imbalances in the private sector, but also in the public one. The Romanian economy is not characterized by diversity, as the shares of the different sectors of the country's GDP illustrate (Figure 2), four sectors generating around $65 \%$ from GDP. It strengthens the character of a poorly structured economy (Bentoiu, Bălăceanu, \& Apostol, 2012). This relatively high degree of concentration doesn't provide a buffer to withstand external 
Sima V., Gheorghe I.G.: A multicriterial Analysis of National Competitiveness...

and internal shocks, despite a relatively large and growing domestic consumption base, being obvious in the annual decrease rate (around $8 \%$ ) during the global crisis, when the Romanian economy showed a low resilience.

Figure 2. Sectoral Value Added, 2006-2015 (\% of GDP)

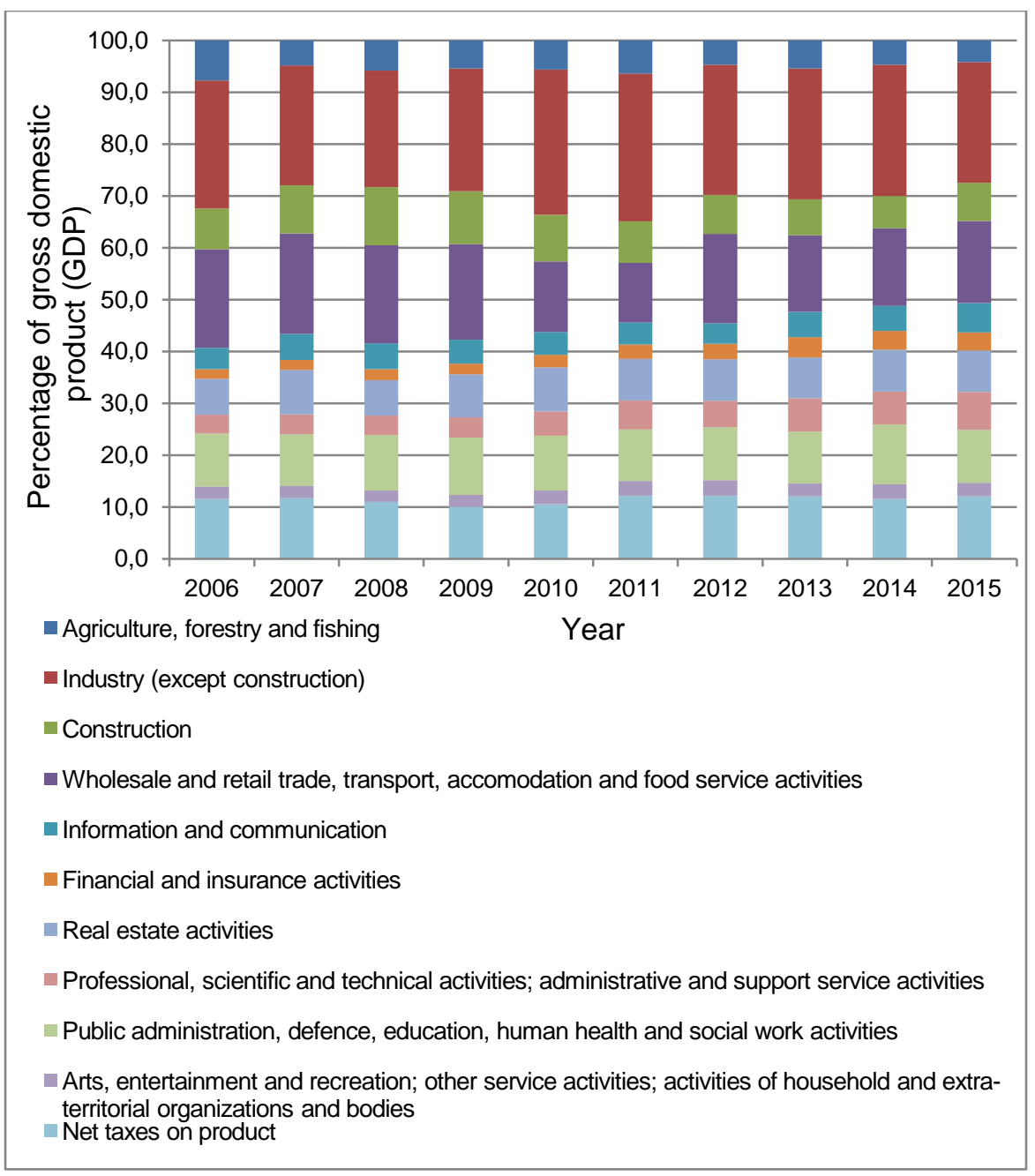

Source: Authors computations, based on Eurostat data, v3.1.18-20160921-5796PROD_EUROBASE, [nama_10_a10]. 
Sima V., Gheorghe I.G.: A multicriterial Analysis of National Competitiveness...

However, starting with 2010 , the Romanian GDP has continuously grown. The restoring has based on the contribution of industry and services. In terms of uses, final consumption expenditure of public administration, changes in inventories and net exports have had a positive influence on GDP. Thus, individual consumption of households and collective consumption of public administration have decreased. Net exports recorded a more pronounced decline. The growth rate of gross fixed capital formation had a negative effect. In this context, attracting of foreign capital is a key issue.

Figure 3. GCl evolution, 2006-2015

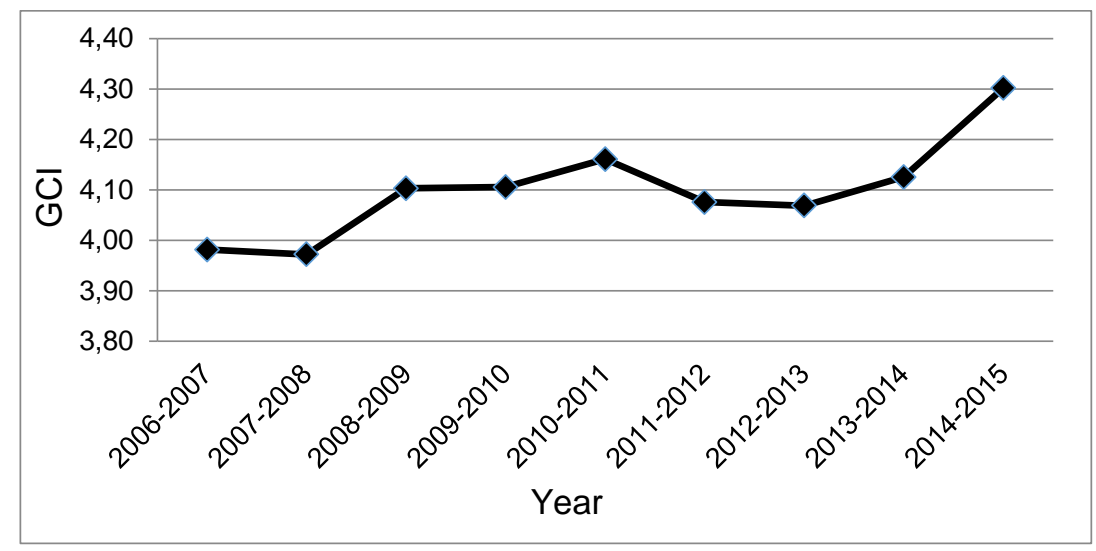

Source: Authors computations, based on the data of The Global Competitiveness Reports (Schwab K. , The Global Competitiveness Report 2006-2007, 2006; Schwab K. , The Global Competitiveness Report 2008-2009, 2008; Schwab K. , The Global Competitiveness Report 2009-2010, 2009; Schwab K. , The Global Competitiveness Report 2010-2011, 2010; Schwab K. , The Global Competitiveness Report 2012 20013, 2012; Schwab K. , The Global Competitiveness Report 2013-2014, 2013; Schwab K. , The Global Competitiveness Report 2014-2015, 2014)

In Romania in the period under review, the $\mathrm{GCl}$ recorded the lowest value during 2007-2008, namely 3.97. Since 2007, becoming a member of EU determined a considerable improvement of the competitiveness of Romania. Thus, during 2008-2011, GCl has registered an upward trend. Importantly, starting in $2013 \mathrm{GCl}$ restarted its upward trend, reaching in 2015 a value of 4.30 (Figure 3). This evolution was due to the fact that, two of the three main drivers of economic growth (health of the macroeconomic environment and status of the public institutions) have achieved significant progress - in terms of Romania's organizational capacity and simplifying the operations of markets. Progress, however, were made shyly and the taken actions often were not followed on a long-term. Besides strategies, plans and programs requested by the EU, Romania need a national competitiveness strategy on 
Sima V., Gheorghe I.G.: A multicriterial Analysis of National Competitiveness...

long-term. Another crucial factor is linked to the country's technological capability. Technologization directly depends on new investments. They can be achieved by accessing European funds. Unfortunately, the absorption rate of European funds in Romania is still low.

Figure 4. EPI evolution, 2006-2016

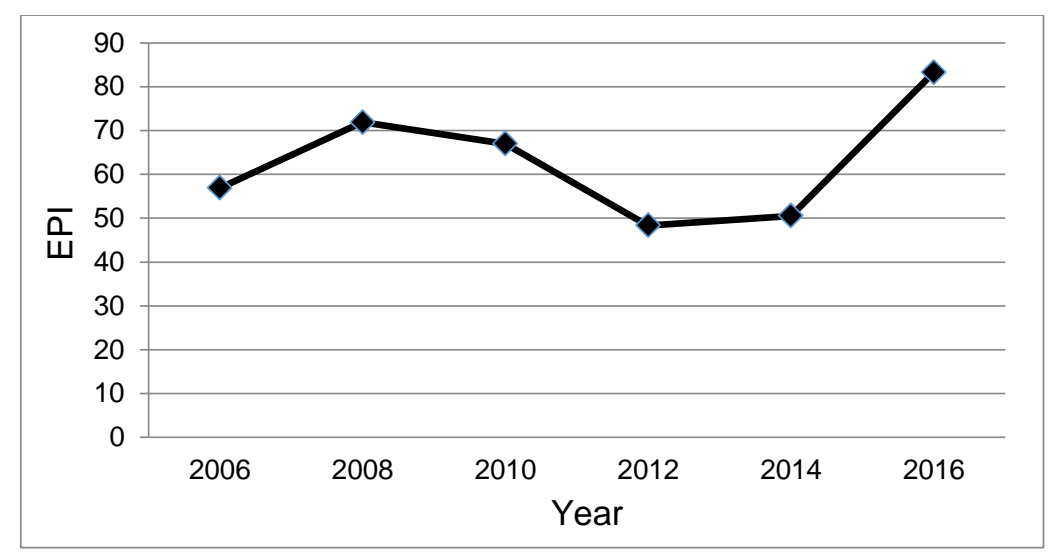

Source: Authors computations, based on Yale University data (Environmental Performance Index)

This index showed how close the European countries are from the established objectives of the environmental policy of their national governments. According to Figure 4, EPl's evolution is like the abovementioned manifestations. Thus, after a downward trend during 2008-2012, Romania has encountered an upward trend, the highest value being mentioned in the 2016 report, namely 83.24. Romania was ranked the 34th among 180 countries. In accordance with this type of evolution Romania may be included in the category of developing countries which have improved in EPI score over the last decade. The reality is that the Index's rankings have been shaken up since the previous iteration following 2016 EPl's innovations, reflecting an improved methodology and new indicators. Top 10 places in the ranking are occupied by EU member countries. This confirms the EU's commitment to achieving a society that does not exceed the carrying capacity of nature begin to bear fruit, the successful example being the case of Finland (2016). However, Romania's case is more complex. Thus, due to the economic crisis, total GHG emissions had a downward trend (from 123.36 million tons of $\mathrm{CO} 2$ equivalent in 2011, to 118.73 million tons $\mathrm{CO} 2$ equivalent in 2012). Thus, Romania has recorded approx. 30 percentage points above the assumed decrease in GHG emissions for 2020 - by $20 \%$ compared to 1990. By applying some energy efficiency measures, but also because of the 
Sima V., Gheorghe I.G.: A multicriterial Analysis of National Competitiveness...

economic crisis, the estimated gross final consumption of energy has a lower value than the forecast of the National Action Plan on energy from renewable sources (NREAP), which will help increasing share of energy from RES in final energy consumption.

Gross domestic product per capita is not an accurate measure of international competitiveness because elements that are not subject to international competition are included in this variable composition (Lall, 2001). In the considered period HDI has recorded annual growth rates which subsequently reflected in the overall growth trend of this indicator. The $2014 \mathrm{HDI}$ value was 0.793 (Figure 5).

Figure 5. HDI evolution, 2010-2014

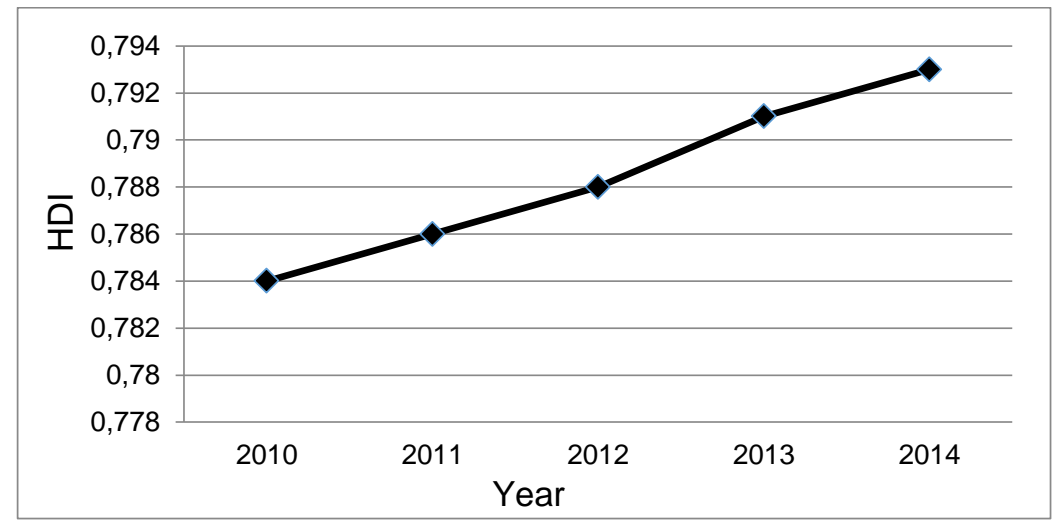

Source: Authors computations, based on Human Development Data ( Human Development Reports)

Analyzing HDI components, Life expectancy at birth and GNI per capita had positive annual growth rates. An exception was the period 2011-2012 when GNI per capita (in 2011 PPP \$) dropped from 17.071 to 17.068 . Mean years of schooling in 2010-2012 increased by 0.1 years per year, but in the past three years, it remained unchanged, respectively, 10.8 years. The situation was worse in the case of Schooling expected years. It has decreased from 14.5 in 2010 to 14.2. Then it remained unchanged until the end of the analyzed period. This can be explained by the decline in living standards because of the economic crisis, which generated, including school dropouts' amplification.

Analyzing the evolution of Romania's economic resilience index during 20082014, its downward trend is established, from 0.336 to 0.294 (Figure 6). This trend is contrary to the trends in the indicators analyzed above, suggesting hidden sources of vulnerability. 
Sima V., Gheorghe I.G.: A multicriterial Analysis of National Competitiveness...

Figure 6. Economic Resilience Index evolution, 2008-2014

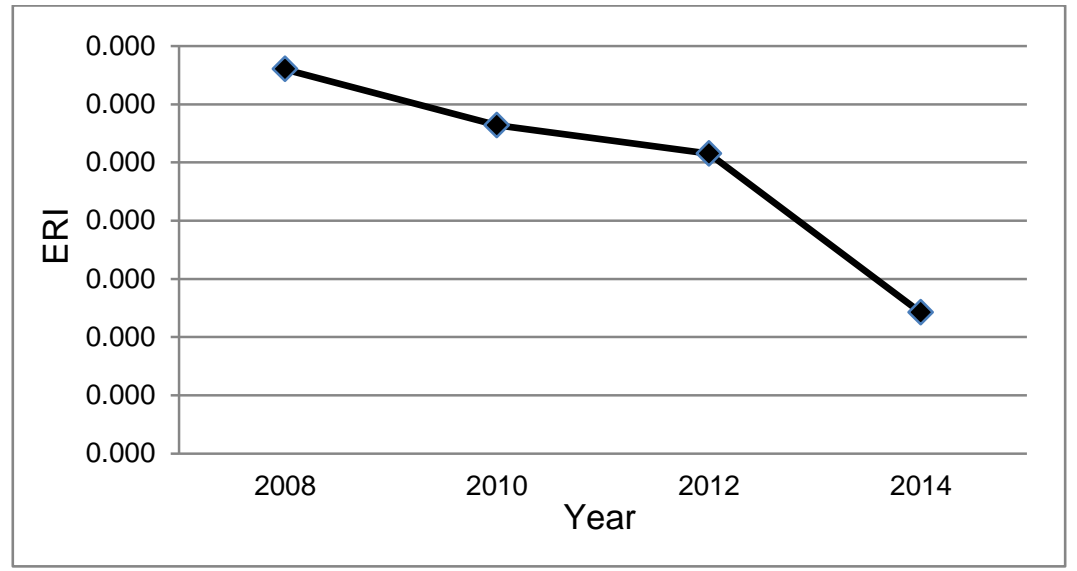

Source: Result of the authors computations

This decline appears to be due largely to a decrease in Social development sub-index and in Governance sub-index (Table 2). Thus, in the governance sub-index, judicial independence is the decreasing factor. Regarding social development sub-index, the education index decreased significantly. Therefore, decision makers should pay attention primarily to these areas.

Table 2. ERI and its components 2008-2014.

\begin{tabular}{|c|c|c|c|c|c|}
\hline Year & $\begin{array}{c}\text { The } \\
\text { macroeconomic } \\
\text { stability sub- } \\
\text { index }\end{array}$ & $\begin{array}{c}\text { The } \\
\text { microeconomic } \\
\text { efficiency index }\end{array}$ & $\begin{array}{c}\text { The governance } \\
\text { index }\end{array}$ & $\begin{array}{c}\text { The social } \\
\text { development } \\
\text { index }\end{array}$ & Resilience index \\
\hline 2008 & 0.148 & 0.067 & 0.275 & 0.854 & 0.336 \\
\hline 2010 & 0.176 & 0.073 & 0.264 & 0.792 & 0.326 \\
\hline 2012 & 0.165 & 0.077 & 0.249 & 0.795 & 0.322 \\
\hline 2014 & 0.024 & 0.077 & 0.277 & 0.798 & 0.294 \\
\hline
\end{tabular}

Source: Authors computations

\section{Conclusions}

This research is justified by the impact of the determinants factors on the social development required by economic progress and sustainable prosperity of the countries across the world. Currently, the concept of competitiveness is closely linked to and even influenced to the human capital. The 2020 EU 
Sima V., Gheorghe I.G.: A multicriterial Analysis of National Competitiveness...

strategy aims the continuous improvement of the quality of life and well-being of present and future generations. In this respect, it promotes a dynamic economy, increasing employment, increasing education level, improve the people health status, increasing social and territorial cohesion, to ensure the protection of the global environment, in peace and security with respect cultural diversity.

In the economic literature, different ways to measure competitiveness are presented, each using specific economic indicators (Waheeduzzaman \& Ryans, 1996; Gardiner, 2003; Durand \& Giorno, 1987). For the study, the relative change of the indicators is of interest (Durand \& Giorno, 1987). Porter stated since in 1990 that the idea of national competitiveness regarded as economic prosperity should be abandoned. Policy makers should consider providing and raising living standards. To achieve these targets, they should pursue increasing the productivity of labor and capital resources (Porter, 1990).

Economic development generating competitiveness will be sustainable only if the following principles have simultaneously complied: (1) The principle of economic performance; (2) The principle of social performance; (3) The principle of environmental performance. The economic performance (quantified by GDP, $\mathrm{HDI}$, and $\mathrm{GCl}$ ) contributes to maintaining and even to developing profitability in the short, medium and long-term at the micro- and macro- economic levels (the concept of eco-economy). Social performance (quantified, also, by $\mathrm{HDI}$, and $\mathrm{GCl}$ ) contributes to obtaining: welfare for all members of society; equity and social justice; social inclusion, cohesion and solidarity; an adequate level of health and education for the population. These last two principles could be related to the eco-welfare. The environmental performance (quantified by $\mathrm{EPI}$ score and $\mathrm{GCl}$ ) contributes to maintaining a stable base of natural resources and avoiding as much as possible excessive exploitation of unrenewable resources (eco-efficiency principle). These variables were analyzed ante-crisis and ex-crisis because we assumed that the economic recession could generate some effects. GCl's evolution can be explained by the fact that it measures how efficiently a country uses available resources and capacity of the state to ensure a high standard of living for its citizens. This development is, on the one hand, according to those above stated and, on the other hand, according to our assumption that competitiveness is determined also by social factors. It had a role increasingly important, which results from the continuous growth of the average value of HDI. The economic crisis has led governments to impose austerity measures that led to falling living standards. Thus, HDl's evolution can be explained by the manifestation of increasingly accentuated concern for human welfare within the European Union. The average EPI score decreased continuously during 2008-2012, which indicates that, although declaratively, all organisms 
Sima V., Gheorghe I.G.: A multicriterial Analysis of National Competitiveness...

are concerned about environmental problems, in reality, things are not quite so.

In other words, an unpolluted environment (clean) based on a solid economic environment ensures the development of a healthy human environment, highly educated, highly cultured. Social actions based on the principles of sustainable development will ensure the future generation that actual generation acted intelligently to achieve economic performance. The level of competitiveness of a country is the engine of its development. The welfare of the population seen by human development index has a fundamental role in increasing the competitiveness level of a country. The human development, which should be seen as a major goal of humanity cannot be sustainable without qualitative economic growth. The economic growth influences human development through the social spending. In turn, a higher human development index can lead to a more consistent and sustainable economic growth. The human development provides improved physical and intellectual abilities of the labor force. They influence the technological level of the economy which, in turn, directly determines the composition and volume of production, exports structure and income distribution. As regards economic factors which influence the competitiveness, it seems that they fail to provide similar contributions, with significant disparities between countries.

The Romanian economy resilience is mainly explained by the low level of competitiveness and productivity of production factors. The obtained outcomes suggest that in addition to national competitiveness assessing, ERI evaluation is important because it can reveal the hidden sources of vulnerability of the economy to external shocks. The final goal is to increase the capacity of averting or recovering the negative effects of external shocks. Policies can help to mitigate the build-up of vulnerabilities in the boom phase of the cycle. This justifies, once more, the appropriateness to assess the economic resilience (ERI).

Regarding mitigating the impact of shock and speeding recovery after a crisis, macroeconomic policies are very important. A cautious approach means building policies that identify and attack vulnerabilities early on. This could significantly decrease risks in future crises. In the field of fiscal policies, this means the accumulation of fiscal surpluses during periods of growth to allow aggressive fiscal stimulus, in the case of a crisis. Effective fiscal policies involve, on the one hand, maintaining low levels of debt and deficit, and, on the other hand, acceptable interest rates for loans. The structural policy also represents a crucial factor in ensuring the resilience of economies to shocks. Thus, they make the junction with macroeconomic policies, determine the speed of adjustment of wages and prices and influence the flows between economic organizations and sectors. A key element here is the labor market policies that can cushion the impact of a shock on the economy by facilitating 
Sima V., Gheorghe I.G.: A multicriterial Analysis of National Competitiveness...

professional reconversion and employers' mobility. Mobility can be aided by a high degree of flexibility of the real estate market which allows workers to quickly and easily move where jobs are available. On the other hand, it can lead to cyclic oscillations. Finally, a lower degree of product market regulation can help decrease the impact and reduce the persistence of shocks. More than that, macro-prudential regulation can limit banking sector instability and excessive pro-cyclicality. In respect of market regulation, a greater liberalization can diminish the impact of shocks and reduce their persistence.

The multifaceted concept of economic resilience must be effective coupled with national competitiveness. The identification of those policy tools enhancing the resilience of the national economy is a difficult problem. In many cases, they come to contradict the long-term growth objectives.

\section{References}

Bentoiu, C., Bălăceanu, C., \& Apostol, D. (2012). Characterization of the state and evolution of the Romanian economy during 2000-2010). Main statistical indicators used. Romanian Statistical Review, 3, pp. 64-76.

Bhanu, M., \& Raghbendra, J. (2003). A Critique of the Environmental Sustainability Index. Australian National University, Discussion Paper, pp. 1-28. Retrieved May 12. 2016, from https://crawford.anu.edu.au/acde/publications/publish/papers/wp2003/wp-econ2003-08.pdf

Briguglio, L. (2003). The Vulnerability Index and Small Island Developing States: A Review of Conceptual and Methodological Issues. AIMS Regional Preparatory Meeting on the Ten Year Review of the Barbados Programme of Action. Praia, Cape Verde. Retrieved September 6, 2016, from http://www.um.edu.mt/_data/assets/pdf_file/0019/44137/vulnerability_paper_se p03.pdf

Briguglio, L., Cordina, G., Farrugia, N., \& Vella, S. (2009). Economic Vulnerability And Resilience: Concepts And Measurements. Oxford development studies, 37(3), pp. 229-247. doi:org/10.1080/13600810903089893.

Burns, T. (2012). The sustainability revolution: A societal paradigm shift. Sustainability, 4(6), pp. 1118-1134. doi:10.3390/su4061118

Caraiani, C. e. (2010). Contabilitatea verde - Strategii transdisciplinare către contabilitatea socială şi de mediu. Bucharest, Romania: Bucharest University of Economic Studies Publishing House.

Commission to the European Parliament, the Council, the European Economic and Social Committee and the Committee of the Regions. (2014). EURO-Lex. Retrieved October 14, 2016, from http://eur-lex.europa.eu: http://eurlex.europa.eu/legal-content/EN/TXT/?uri=CELEX\%3A52014DC0398R(01)

Danaher, K. B. (2007). Building the green economy: Success stories from the grass roots. Sausalito: PoliPoint Press. 
Sima V., Gheorghe I.G.: A multicriterial Analysis of National Competitiveness...

Dobre, E., Stanila, G. O., \& Brad, L. (2015). The Influence of Environmental and Social Performance on Financial Performance: Evidence from Romania's Listed Entities. Sustainability, 7(3), pp. 2513-2553. doi:10.3390/su7032513

Durand, M., \& Giorno, C. (1987). Indicators of international competitiveness: Conceptual aspects and evaluation. OECD Economic Studies, 9, pp. 147-182.

Edwards, A. (2005). The sustainability revolution: Portrait of a Paradigm Shift. Gabriola Island.

Ellen MacArthur Foundation. (2013). Towards the Circular Economy. Retrieved October 14, 2016, from http://eur-lex.europa.eu: https://www.ellenmacarthurfoundation.org/assets/downloads/publications/EllenMacArthur-Foundation-Towards-the-Circular-Economy-vol.1.pdf

Esty, D. C., \& Winston, A. S. (2006). Green to gold: How smart companies use environmental strategy to innovate, create value, and build competitive advantage. U.S.A.: New Haven Publisher: Yale University Press.

Gardiner, B. (2003). Regional Competitiveness for Europe Indicators-Audit, Database Construction and Analysis. Regional Studies, Association International Conference. Pisa.

Gwartney, J. D., Lawson, R. A., \& Clark, J. R. (2002). Economic freedom of the world. Vancouver:: Fraser Institute.

Haberland, T. (2008). Analysis of the Yale Environmental Performance Index (EPI). Dessau-Roßlau: Federal Environment Agency (Umweltbundesamt). Retrieved June 18, 2016, from https://www.umweltbundesamt.de/sites/default/files/medien/publikation/long/3429 .pdf

Haq, M. u. (1999). Reflections on Human Development. New York: Oxford University Press.

Hawken, P. (2008). Blessed unrest: How the largest social movement in history is restoring grace, justice, and beauty to the world. New York, U.S.A.: Penguin Books .

Jacobson, M. Z., \& Delucchi, M. A. (2009). A path to sustainable energy. Scientific American, 301, pp. 58-65. doi:10.1038/scientificamerican1109-58

Kasimovskaya, E., \& Didenko, M. (2013). International Competitiveness and Sustainable Development: are they apart, are they together? A quantitative approach. SBS-JABR, 2, pp. 37-51.

Kuznets, S. (1955). Economic Growth and Income Inequality. The American Economic Review, $X L V(1), 1-28$.

Lall, S. (2001). Comparing National competitive Performance: An Economic Analysis of World Economic Form's Competitiveness Index. World development, 29(9), pp. 1501-1525. Retrieved October 22, 2016, from http://biblioteca.fundacionicbc.edu.ar/images/3/34/Politicas_2.pdf

Marcus, A. A., Geffem, D. A., \& Sexton, K. (2002). Reinventing environmental regulation: Lessons from Project XL; Resources for the Future. Washington D.C., U.S.A.

Matei, M., Popescu, C., \& Radulescu, I. (2011). The climate change related products and social responsible investment. The 5th WSEAS International Conference on Management, Marketing and Finances (MMF' 11): Recent Researches in Sociology, Financing, Environment \& Health Sciences (pp. 132-137). Playa Meloneras, Gran Canaria, Canary Islands, Spain: WSEAS Press. 
Sima V., Gheorghe I.G.: A multicriterial Analysis of National Competitiveness...

Orr, D. W. (1994). Earth in mind: On education, environment, and the human prospect. Washington, D.C., U.S.A.: Island Press.

Porter, M. E. (1990). The Competitive Advantage of Nations. New York: Free Press.

Porter, M. E., Sachs, J. D., Warner, A. M., Cornelius, P. K., Levinson, M., \& Schwab, K. (2000). The Global Competitiveness Report 2000. World Economic Forum. New York: Oxford University Press, Inc. Retrieved August 12, 2016, from http://www.cid.harvard.edu/archive/res/gcr_2000_overview.pdf

Programul de Convergenţă, 2016-2019. (2016, Aprilie). Retrieved October 27, 2016, from http://ec.europa.eu: http://ec.europa.eu/europe2020/pdf/csr2016/cp2016_romania_ro.pdf.

Radu, M. (2012). Empirical study on the indicators of sustainable performance - the sustainability balanced scorecard, effect of strategic organizational change. Amfiteatru economic, 14(32), pp. 375-393.

Röhn, O. S. (2015). Economic resilience: A new set of vulnerability indicators for OECD countries. OECD Economics Department Working Papers(1249), pp. 5-6. doi:10.1787/5jrxhgjw54r8-en

Russo, M. V. (2008). Environmental management: Readings and cases (2nd ed.). Los Angeles, U.S.A.: Sage Publications.

Sala-I-Martin, X. G. (2012). The Global Competitiveness Index 2011-2012: Setting the Foundations for Strong Productivity. World Economic Forum. Retrieved August 12, 2016, from http://www3.weforum.org/docs/WEF_GCR_Report_2011-12.pdf

Sala-I-Martin, X., \& Artadi, E. (2005). The Global Competitiveness Index in The Global Competitiveness Report 2004-2005. World Economic Forum. New York: Palgrave Macmillan. Retrieved August 12, 2016, from http://www.salaimartin.com/media/pdf/1.3_The_Global_Comp_Index.pdf

Schwab, K. \&. (2009). Moving to a New Global Competitiveness Index in The global competitiveness report 2008-2009. The Global Competitiveness Report 20082009, World Economic Forum. Retrieved November 25, 2015, from Indexhttp://www.weforum.org/pdf/GCR08/Chapter\%201.2.pdf

Schwab, K., Porter, M. E., \& Sachs, J. D. (2002). The Global Competitiveness Report 2001-2002. World Economic Forum. New York: Oxford University Press. Retrieved August 12, 2016, from http://citeseerx.ist.psu.edu/viewdoc/download?doi=10.1.1.476.4940\&rep=rep1\&ty pe $=$ pdf

Sima, V., \& Gheorghe, I. G. (2014). Analyze of environmental performance in Romania based on environmental performance index. Annals of the "Constantin Brâncuşi” University of Târgu Jiu. Economy Series, 3, pp. 101-104.

Starik, M., \& Heuer, M. (2002). Strategic inter-organizational environmentalism in the U.S.: A multi-sectoral perspective of alternating eco-policy roles. Business Strategy and the Environment. 11(4), pp. 221-235. doi:10.1002/bse.334

Wackernagel, M. (2001, February 10). Shortcomings of the Environmental Sustainability Index. Notes by Mathis Wackernagel, Redefining Progress. Retrieved 14 June, 2016, from http://www.antilomborg. com/ESI\%20critique.rtf

Waheeduzzaman, A., \& Ryans, J. (1996). Definition, perspectives and understanding of international competitiveness. Competitiveness Review, 6.

Yale University. (n.d.). Environmental Performance Index. Retrieved May 23, 2014, from http://epi.yale.edu/ 
Sima V., Gheorghe I.G.: A multicriterial Analysis of National Competitiveness...

YaleUniversity. (2016). Global metrics for the environment. The Environmental Performance Index ranks countries' performance on high-priority environmental issues. Retrieved October 27, 2016, from www.epi.yale.edu

Zaman, G., \& Vasile, V. (2014). Conceptual framework of economic resilience and vulnerability, at national and regional levels. Romanian Journal of Economics, $39(2(48))$, p. 6. 